\title{
Ceragenins as Mimics of Endogenous Antimicrobial Peptides
}

\author{
Marjan M Hashemi ${ }^{1}$, Brett S Holden ${ }^{1}$, Bonita Durnaś ${ }^{2}$, Robert Bucki $^{3}$ and Paul B Savage ${ }^{1^{\star}}$ \\ ${ }^{1}$ Department of Chemistry and Biochemistry, Brigham Young University, Provo, USA \\ ${ }^{2}$ Department of Microbiology and Immunology, The Faculty of Health Sciences, Jan Kochanowski University, Kielce, Poland \\ ${ }^{3}$ Department of Microbiological and Nanobiomedical Engineering, Medical University of Białystok, Poland \\ "Corresponding author: Paul B Savage, Department of Chemistry and Biochemistry, Brigham Young University, C100 BNSN, Provo, USA, Tel: 1801422 4020; Fax: 1 \\ 801422 0153; E-mail: pbs@byu.edu
}

Received date: April 18, 2017; Accepted date: May 10, 2017; Published date: May 17, 2017

Copyright: (c) 2017 Hashemi MM, et al. This is an open-access article distributed under the terms of the Creative Commons Attribution License, which permits unrestricted use, distribution, and reproduction in any medium, provided the original author and source are credited.

\begin{abstract}
Ceragenins are small molecule mimics of endogenous antimicrobial peptides (AMPs), and as such display broadspectrum antimicrobial activity. These molecules are derived from a common bile acid and can be prepared at a large scale. Because ceragenins are not peptide based, they are not substrates for proteases. Gram-negative and positive bacteria are susceptible to ceragenins, including drug resistant organisms. Although ceragenins and colistin have common features, ceragenins retain full antibacterial activity against colistin-resistant Gram-negative bacteria. Bactericidal activity of ceragenins involves selective association with bacterial membranes followed by membrane depolarization. Due to this mechanism of action, which provides bactericidal activity against sessile bacteria, ceragenins eradicate established biofilms. Lipid-enveloped viruses (e.g. vaccinia) are deactivated by ceragenins, and topical application of a lead ceragenin decreases transmission of the virus in skin in a murine model. More recently, the activities of ceragenins against fungal pathogens have been reported, with minimum inhibition concentrations comparable to clinically used anti-fungal agents. In addition to antimicrobial activities, ceragenins have been shown to display some of the "secondary" activities attributed to AMPs. In vivo use of ceragenins to eradicate biofilms, prevent infection and accelerate bone growth demonstrate some of the types of applications in which ceragenins may be used to augment or replace activities of endogenous AMPs.
\end{abstract}

Keywords: Ceragenins; Antimicrobial peptides; Drug-resistant bacteria; Drug-resistant fungi; Lipid-enveloped virus

\section{Introduction}

Excessive antibiotic use in humans, agriculture, and animal care has led to development of drug resistance in microorganisms [1]. As a result, substantial effort is being expended to develop new therapeutics and mechanisms for controlling microbial growth to avoid entering a "post-antibiotic" era in which commonly used antibiotics are no longer effective in treating infections [2,3]. For example, according to the U.S. Center for Disease Control and Prevention (CDC), each year more than two million people in the United States are infected by drugresistant bacteria, and a substantial portion of those infections are caused by multidrug-resistant bacteria [4].

For eons, antimicrobial peptides (AMPs) have played a central role in innate immunity against bacteria, fungi and lipid enveloped viruses [5-9]. The diversity of their primary sequences suggests independent evolution, and despite their ubiquity, bacteria generally remain susceptible to AMPs. Most AMPs are cationic and facially amphiphilic, and this morphology allows them to selectively associate with bacterial membranes and cause defects in the membranes sufficient for cell death.

The broad-spectrum bactericidal activities of AMPs and the idea that bacteria are unlikely to develop high levels of resistance have led to efforts to use AMPs clinically to augment or replace endogenous AMPs. However, these efforts have been complicated due to the high cost of peptide therapeutics, relative to small molecules, and the short half-lives of AMPs in the presences of proteases [10-13].
In addition to the antimicrobial activities of AMPs, these compounds have been characterized with "secondary" properties including acceleration of wound healing [14]. Among their activities, AMPs display anti-inflammatory properties, through sequestration of bacterial endotoxins, promotion of cell migration into wound beds and neovascularization. Thus, the impact of AMPs in wounds involves clearance of bacteria from the wound bed, reduction of local inflammation and facilitation of wound restructuring $[15,16]$.

Ceragenins were developed as non-peptide mimics of AMPs. The ceragenins are based on a common bile acid, cholic acid, and mimic the amphiphilic morphology of AMPs (Figure 1). This morphology endows ceragenins with the antimicrobial activities of AMPs, which include broad-spectrum activity against bacterial, fungi and lipidenveloped viruses. The simplicity of ceragenins allows preparation on a large scale, and because they are not peptide based, they are not substrates for proteases [17-20].

Of particular importance are the activities of ceragenins against highly drug-resistant organisms. For example, ceragenins retain activity against methicillin-resistant Staphylococcus aureus, [21] colistin-resistant Klebsiella pneumoniae [22,23] and fluconazoleresistant Candida albicans [24] Efforts to generate resistance to selected ceragenins have resulted in relatively small changes in susceptibility, due to modifications of the lipid A portion of LPS, but high levels of resistance have not been observed [22,25]. Multiple in vivo studies have demonstrated that ceragenins are well tolerated in specific tissues and retain their antibacterial activities [26-28]. In these studies, as well as in vitro studies [29,30], evidence of "secondary" properties of ceragenins, mimicking those of AMPs, have been observed, including bacterial endotoxin sequestration, promotion of 
cell migration into wound bends, neovascularization and acceleration of bone regrowth [31]. These properties, coupled with their broad antimicrobial activities, make ceragenins attractive targets for clinical development in replacing deficiencies of endogenous AMPs or augmenting their activities through additive or synergistic effects.

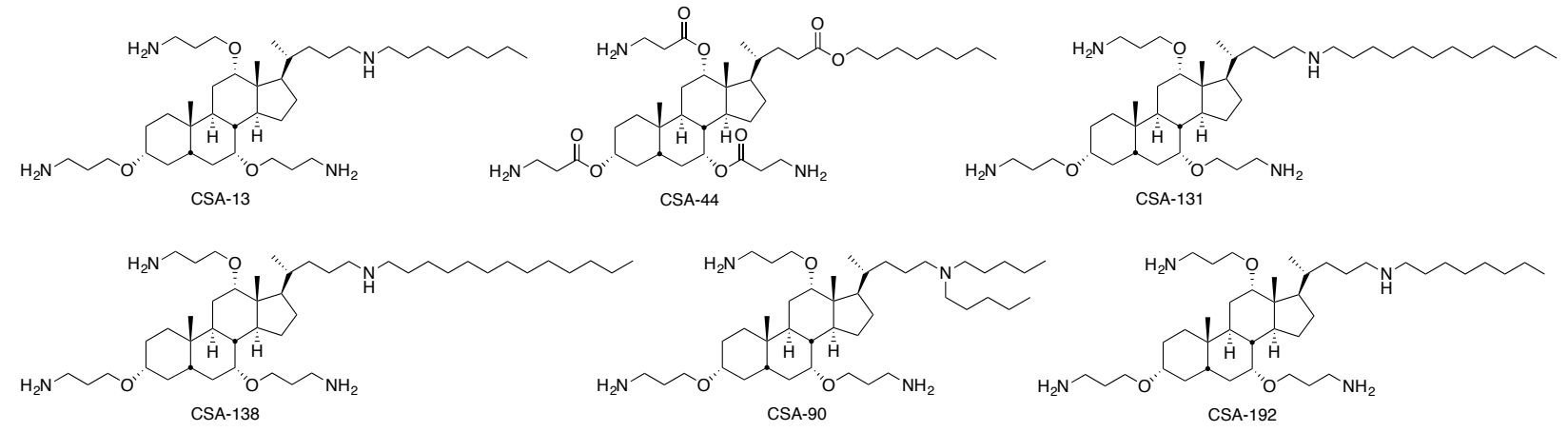

Figure 1: Structures of ceragenins CSA-13, CSA-44, CSA-90, CSA-131, CSA-138 and CSA-192.

\section{Mechanism of action}

As mimics of AMPs, ceragenins selectively target bacterial membranes [32,33], and association of ceragenins with the cytoplasmic membranes of bacteria is sufficient to cause cell death. Epand et al. [34] used the ML-35p strain of Escherichia coli to verify that ceragenins are able to traverse the outer membranes of Gramnegative bacteria, and observation of cytoplasmic membrane depolarization correlated well with bactericidal activity, suggesting that formation of only minor membrane defects can lead to bacterial death. Similarly, many AMPs cause transient ion fluxes through bacterial membranes, and these have been correlated to antibacterial activities [35-37]. Multiple models, including the "carpet" model, have been used to explain the origins of these ion fluxes. This model involves AMP association, via ionic interactions, with bacterial membranes, and when sufficient local concentrations of the antimicrobial are reached, patches of membrane are disrupted, allowing ion flux [18,38-41]. Morphological changes in Gram-negative bacteria in response to AMPs include blebbing of the outer membranes, [42-44] and the same type of blebbing has occurs upon treatment of Gram-negative bacteria with ceragenins [33,45] Bacterial endotoxins are constituents of bacterial membranes, [46] and the affinity of ceragenins for bacterial membranes translates into the ability of ceragenins to sequester bacterial endotoxins and inhibit innate immune recognition. Bucki et al. [47] demonstrated that a lead ceragenin, CSA-13, binds to lipopolysaccharide (LPS) and inhibits its ability to activate TLR-4, preventing NF-kB translocation to the nucleus; NF-kB translocation leads to inflammatory cytokine production and release. Isogai et al. [48] showed that CSA-13 sequesters LPS from multiple types of bacteria commonly found in the oral cavity at concentrations comparable to AMPs. In addition, they showed that CSA-13 also binds to lipoteichoic acid, an endotoxin found in Gram-negative and positive bacteria.

The understanding of how AMPs and ceragenins interact with viral lipid envelopes is less well understood. The activities of AMPs against lipid-enveloped viruses has been well established, but a full description of their antiviral activities has not been realized [49,50]. Howell et al. [51] studied the activities of ceragenins against vaccinia virus. They showed that CSA-13, at a concentration comparable to the human AMP, LL-37, caused viral disruption. Transmission electron micrographs showed substantial changes in the lipid envelop after treatment with CSA-13. Use of a fluorophore-labeled ceragenin allowed observation of selective binding of the ceragenin to the envelop of vaccinia virus over human keratinocytes. Topical administration of CSA-13 on vaccinia-inoculated mice resulted in a significant decrease in the number of satellite lesions, and preincubation of the virus with CSA-13 inhibited viral replication. Notably, in these studies, Howell et al. [51] observed that treatment of human keratinocytes with CSA-13 induced LL-37 and beta-defensin 3 production.

\section{Antimicrobial spectrum ceragenin activity}

\section{Antibacterial activity}

As mimics of AMPs, ceragenins display broad-spectrum activity against Gram-negative and positive bacteria, including activity against drug-resistant organisms [33,52-54]. Studies of bacteria susceptibility to ceragenins has focused on clinical isolates and bacteria, primarily clinical isolates, endemic to specific areas of the human body. For example, Isogai et al. [48] surveyed the susceptibility of a collection of Gram-negative and positive bacteria from the oral cavity to CSA-13 and found minimum inhibitory concentrations (MICs) of 1 to 16 $\mu \mathrm{g} / \mathrm{ml}$; Bucki et al. [55] determined the susceptibility of bacteria associated with oral and upper respiratory tract infections to ceragenins and LL-37. Ceragenin MICs against bacteria included measurements with $S$. aureus and $S$. epidermidis, Streptococcus strains (S. salivarius, $S$. sanguinis, $S$. mutanss, $S$. pneumoniae, $S$. pyogenes) and other pathogens including Neisseria meningitis B and C, Moraxella catarrhalis and Tannerella forsythensis. MICs ranged from 0.7 to $46.8 \mu \mathrm{g} / \mathrm{ml}$ with ceragenins, and those with LL-37 ranged from 14 to $448 \mu \mathrm{g} / \mathrm{ml}$. Notably, the highest MICs for the ceragenins were with Lactobacillus casei ( 44.8 to $46.8 \mu \mathrm{g} / \mathrm{ml}$ ), and the MIC was also elevated with LL-37 $(224 \mu \mathrm{g} / \mathrm{ml})$. This species of bacteria is considered a probiotic, and it is likely that it has adapted to the presence of AMPs and is similarly resistant to ceragenins. Negatively charged biopolymers in the oral cavity and respiratory tract have the potential to bind to AMPs and ceragenins, thereby deactivating them, and these compounds may increase during infection and biofilm formation. Bucki et al. $[40,46]$ showed that DNA, F-actin, and salivary mucins can partially inhibit LL-37 antibacterial activity, but CSA-13 remains bactericidal activity in their presence $[47,56]$. A focal point in 
determining the antibacterial efficacy of ceragenins has been with Gram-negative bacteria, including drug resistant strains. Treatment options for infections caused by Gram-negative bacteria are limited, as compared to Gram-positive bacteria, [57] due to the permeability barrier provided by the outer membranes of Gram-negative bacteria and the efflux pumps therein, and ceragenins retain activity against drug-resistant Gram-negative bacteria [58].

Susceptibility of 40 drug-resistant strains of Pseudomonas aeruginosa, isolated from cystic fibrosis patients to ceragenins CSA-13 and CSA-131 was significantly higher than to LL-37 [59]. MICs of the ceragenins were $0.6-16 \mu \mathrm{g} / \mathrm{ml}$, while those with LL-37 were $32-256$ $\mu \mathrm{g} / \mathrm{ml}$ respectively. MICs of these strains with tobramycin were 4-256 $\mu \mathrm{g} / \mathrm{ml}$. In a related study, Bozkurt-Guzel et al. $[60,61]$ showed that CSA-13 retains activity against tobramycin-resistant $P$. aeruginosa isolates from cystic fibrosis patients and carbapenem-resistant Acinetobacter baumannii isolates from bacteremia patients. Of increasing concern is the emergence of colistin resistance among Gram-negative bacteria. Colistin is often considered an antibiotic of "last resort," and colistin-resistance is typically accompanied by high levels of resistance to other antibiotics $[62,63]$ because colistin is peptide based and cationic, similar to AMPs, it is possible that colistin resistance translates into resistance to AMPs and ceragenins.

Vila et al. [64] compared the susceptibility of colistin-resistant and susceptible isolates of $P$. aeruginosa and $A$. baumannii to ceragenins CSA-13, CSA-44, CSA-131 and CSA-138. MICs were identical or comparable with both the colistin-resistant and susceptible isolates, with MIC90s ranging from 2-8 $\mu \mathrm{g} / \mathrm{ml}$. Hashemi et al. [22] determined susceptibility of colistin-resistant isolates of Klebsiella pneumoniae to selected ceragenins and AMPs (Table 1). For most ceragenins, MICs were relatively low, independent of MICs with colistin. Two of the AMPs tested (LL-37 and magainin I) were relatively weakly active against all of the strains, while cecropin gave much lower MICs.

\begin{tabular}{|l|l|l|l|l|l|l|l|l|l|}
\hline Strains & Colistin & CSA-13 & CSA-44 & CSA-131 & CSA-138 & CSA-142 & LL-37 & Cecropin A & Magainin 1 \\
\hline $\begin{array}{l}\text { K. pneumoniae } \\
\text { (ARLG-1127) }\end{array}$ & 32 & 2 & 1 & 1 & 2 & 2 & 64 & 2 & 64 \\
\hline K. pneumoniae (ARLG-1340) & 100 & 2 & 1 & 1 & 3 & 4 & 100 & $\mathrm{~nm}$ & $\mathrm{~nm}$ \\
\hline K. pneumoniae (ARLG-1349) & 16 & 2 & 1 & 3 & 3 & 8 & 64 & 4 & 64 \\
\hline $\begin{array}{l}\text { K. pneumoniae } \\
\text { (ARLG-1360) }\end{array}$ & 64 & 2 & 1 & 2 & 6 & 6 & 100 & 4 & 150 \\
\hline K. pneumoniae (ARLG-1389) & 200 & 6 & 2 & 3 & 8 & 8 & 100 & 4 & 4 \\
\hline K. pneumoniae (ARLG-1406) & 64 & 3 & 1 & 3 & 6 & 16 & 64 & 4 & 200 \\
\hline $\begin{array}{l}\text { K. } \\
\text { (ATCC-13883) }\end{array}$ & 2 & 2 & 1 & 1 & 3 & 3 & 32 & 2 & 100 \\
\hline A. paumannii (ATCC-19606) & 1 & 3 & 2 & 2 & 3 & 6 & 16 & 4 & 64 \\
\hline P. aeruginosa (ATCC-27853) & 1 & 2 & 2 & 2 & 2 & 5 & 32 & 4 & 32 \\
\hline
\end{tabular}

Table 1: MICs $(\mu \mathrm{g} / \mathrm{ml})$ of colistin, selected ceragenins and AMPs against Gram-negative bacteria including K. pneumoniae, A. baumannii and P. aeruginosa.

Isolation of drug-resistant forms of Helicobacter pylori have led to concerns about the inability to eradicate chronic infections leading to gastric adenocarcinoma [65].

An in vitro study of CSA-13 susceptibility of seven strains of $H$. pylori (including clarithromycin and/or metronidazole-resistant strains) indicated MBCs of $0.275-8.9 \mu \mathrm{g} / \mathrm{ml}$ with CSA-13, while MBC values with LL-37 and WLBU2 (an engineered antimicrobial peptide) were $100-800$ and $17.8-142 \mu \mathrm{g} / \mathrm{ml}$, respectively [66].

In a further study of the susceptibility of $H$. pylori to ceragenins, McGee et al. [67] showed that membrane incorporation of cholesterol decreased substantially the susceptibility of these bacteria to ceragenins. This effect is likely due to changes in the membrane fluidity caused by cholesterol content.

\section{Sporicidal activity}

Sporulation processes in bacteria, including those from the genera Bacillus and Clostridium, enhance survival in extreme environments and decrease susceptibility to antibiotics and disinfectants.
Considering the broad spectrum of antimicrobial activity of ceragenins, Bucki et al. [68] evaluated the sporicidal activity of CSA-13 against Bacillus subtilis. CSA-13 association with B. subtilis spores caused permeabilization of the spore membrane, and significantly lowered levels of calcium dipicolinic acid in the core. Since, dipicolinic acid release proceeds spore transformation into vegetative cells, it is likely that the ability of CSA-13 to eradicate dormant forms is associated with the ability to induce their germination.

Figure 2 shows TEM images of CSA-13-treated and untreated spores. Notably, assessment of surface electrical properties of spores and vegetative cells through zeta potential illustrated that CSA-13 has a higher affinity for spores than for vegetative cells, indicating that the spores present a higher level of negative charges on their surfaces as compared to vegetative cells. This activity of CSA-13 suggests that it may find use in eradicating not only vegetative forms of bacteria but spore forms as well. 

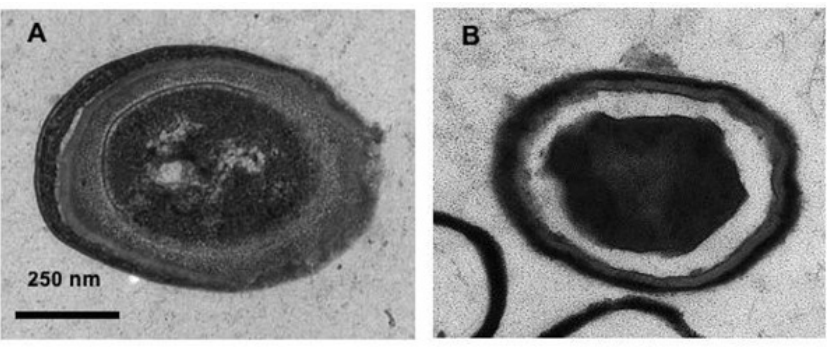

Figure 2: TEM micrographs of a Bacillus subtilis spore before (panel A) and after treatment with CSA- $13\left(50 \mu \mathrm{M}\right.$ at $\left.70^{\circ} \mathrm{C}\right)$ (panel B).

\section{Anti-fungal activity}

Due to emerging resistance of fungi to commonly used antibiotics, the need for development of novel effective antifungal agents has become increasingly recognized [69-71]. Antifungal activities of AMPs have been reported, $[49,72]$ and as mimics of AMPs, ceragenins were anticipated to have antifungal activities. Bucki et al. [24] determined the antifungal activities of ceragenins CSA-13, CSA-131 and CSA-192 and compared these to those of LL-37, a synthetic, anti-fungal AMP (omiganan) and commonly-used antifungal agents amphotericin $\mathrm{B}$ and fluconazole. MICs and minimum fungicidal concentrations (MFCs) for clinical isolates of $C$. albicans are given in Table 2. Ceragenins CSA-13 and CSA-192 displayed comparable activity to amphotericin B, and MICs and MFCs were much lower with ceragenins than with LL-37, omiganan and fluconazole. Against a broad array of fungal strains, including those from the genera Candida, Cryptococcus, Aspergillus, Scedosporium, Rhizopus and Blastomyces, CSA-131 proved to be the most active of compounds tested, with MICs ranging from 1 to $4 \mu \mathrm{g} / \mathrm{ml}$. As with bacteria, treatment of $C$. albicans caused perturbations in the morphology of cells, suggesting that ceragenins impact cell membranes (Figure 3). The activities of ceragenins against both bacteria and fungi suggest that they have potential as antimicrobial agents against mixed infections.

\begin{tabular}{|c|c|c|c|c|c|c|c|}
\hline Strains & CSA-13 & CSA-131 & CSA-192 & LL-37 & Omiganan & Amphotericin B & Fluconazole \\
\hline C. albicans 1407 & $0.5[1]$ & $8[16]$ & $2[4]$ & $64[128]$ & $64[128]$ & $1[1]$ & $128[128]$ \\
\hline C. albicans 1408 & $1[1]$ & $8[8]$ & $1[2]$ & $>256[>256]$ & $64[128]$ & $1[1]$ & $16[32]$ \\
\hline C. albicans 1409 & $4[4]$ & $32[32]$ & $2[4]$ & $>256[>256]$ & $64[128]$ & $0.5[1]$ & $16[32]$ \\
\hline Candida species & $0.5[1]$ & $8[16]$ & $1[2]$ & $64[128]$ & $128[128]$ & $1[2]$ & $>256[>256]$ \\
\hline
\end{tabular}

Table 2: MICs [MFCs] ( $\mu \mathrm{g} / \mathrm{ml})$ of selected ceragenins, LL-37, omiganan, amphotricin B and fluconazole against Candida strains.
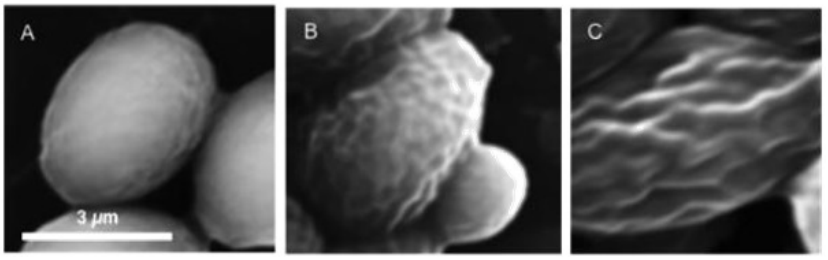

Figure 3: Scanning electron micrographs of untreated C. albicans cells (panel A) and cells subjected to CSA-13 at $10 \mu \mathrm{M}$ (Panel B) and $50 \mu \mathrm{M}$ (panel C).

\section{Antibiofilm activity}

Biofilms are microbial communities with altered phenotypes, relative to planktonic or free-growing microorganisms, that agglomerate through a extracellular polymeric matrix [73,74]. The impact of biofilms, both bacterial and fungal, are increasingly recognized as threats to public health due to the fact that biofilm formation is involved in more than $60 \%$ of bacterial infections, as well as being recognized as a causative agent in most medical device-related infections [75,76]. In their biofilm forms, bacteria and fungi are resistant to most antimicrobials, due to decreased metabolism and the barrier provided by the extracellular matrix [77-79]. The relatively small size of ceragenins allows them to permeate this matrix, and because their antimicrobial activity does not require that organisms be actively growing, they eradicate biofilms at relatively low concentrations $[80,81]$.

Pollard et al. [82] compared the antibiofilm activity of CSA-13 to ciprofloxacin with established bacterial biofilms in a bioreactor developed at the Centers for Disease Control. CSA-13 proved to be better than ciprofloxacin against biofilms formed from methicillinresistant $S$. aureus. Nagant et al. [83] conducted further studies using confocal laser scanning microscopy of biofilms of $P$. aeruginosa and their responses to CSA-13. Images revealed that the ceragenin effectively penetrated an established biofilm within $30 \mathrm{~min}$ and caused cell death without substantial changes to the extracellular matrix. In a later study, Nagant et al. [80] investigated the relationship between zeta potential of different strains of $P$. aeruginosa and the ability of CSA-13 to prevent biofilm formation. At a relatively low concentration (1 $\mu \mathrm{g} / \mathrm{ml}$ ) CSA-13 prevented biofilm formation, and the strains most strongly affected by the ceragenin were those with a zeta potential lower than $-50 \mathrm{mV}$. This observation is consistent with the model of ceragenins interacting with bacterial membranes through ionic interactions.

Recently, the effects of CSA-13, CSA-131 and LL-37 on biofilms formed by drug-resistant $P$. aeruginosa were evaluated, including the Liverpool epidemic strain, a dominant strain of $P$. aeruginosa found in the airways of cystic fibrosis patients [59]. Not only did ceragenins prevent biofilm formation better than LL-37, but ceragenins retained antibiofilm activity even in presence of polyelectrolytes such as Pf1, Factin, and DNA, which can induce biofilm formation.

Comparative antibiofilm activities of ceragenins CSA-13 and CSA-131 and LL-37 on biofilms formed from Candida albicans in 
presence of DNA, which stimulates fungal biofilm formation, demonstrated that each of the compounds inhibited the DNAdependent biofilm growth, and that ceragenins exhibited a stronger inhibitory effect on development of biofilm and maintained that effect for a much longer period of time than LL-37 [20]. Additionally, the combination of DNase I with both LL-37 and ceragenins improved their inhibitory effect on biofilm formation by breaking down complexes of DNA with either LL-37 or ceragenins, which are then more able to penetrate biofilm matrices.

\section{Antiviral activity}

AMPs have been characterized as antiviral agents with activity against lipid-enveloped viruses [84]. Pox viruses are lipid enveloped, and LL-37 and its murine equivalent have been shown to play a central role in inhibition of propagation of vaccinia virus (cow pox). Deficiencies in LL-37 may allow propagation of vaccinia virus (the live-virus vaccine for small pox) in humans. Howell et al. [51] studied the antiviral activity of CSA-13 against vaccinia virus and showed that it inactivates $60 \%, 91 \%$ and $96 \%$ of the virus at 5,10 , and $25 \mu \mathrm{M}$, respectively. Microscopy of vaccinia virus with CSA-13 and LL-37 showed similar morphological changes to the virus with apparent damage to the envelope and internal structure. Topical administration of CSA-13 to mice infected with vaccinia virus showed that satellite lesions, monitored for 10 days, were substantially suppressed. In a companion study, fluorophore-labeled CSA-13 was shown to penetrated the outer layers of the skin and thereby gain access to the virus during infection.

\section{Anti-parasite activity}

Investigations of the anti-parasite activities of ceragenins have included studies with Trypanosoma cruzi, the causative agent of Chagas disease, Leishmania major, Acanthamoeba castellanii and Trichomonas vaginalis, one of the most prevalent protozoan infections in humans. Lara et al. [85] reported ceragenin activity against trypanosomatids. In an in vitro study of ceragenins CSA-8, CSA-13, and CSA-54 with T. cruzi trypomastigotes and L. major promastigotes, CSA-13 gave an $\mathrm{LD}_{50}$ of ca. 9 and $5 \mu \mathrm{M}$, respectively. Polat et al. [86] observed activity of CSA-13 against $A$. castellanii at concentrations ranging from 25 to $100 \mu \mathrm{g} / \mathrm{ml}$. This protozoan is the causative agent of acanthamoeba keratitis, which is a rare but devastating infection of the cornea often associated with wearing of contact lenses. $T$. vaginalis is a highly contagious, sexually-transmitted protozoan parasite, hosted only in humans. Activities of ceragenins CSA-13, CSA-44, CSA-131 and CSA-138 were evaluated against metronidazole-susceptible and resistant organisms. With the exception of CSA-44, these ceragenins, at a concentration of $50 \mu \mathrm{M}$, eliminated a four-log inoculum of either organism within approximately 24 hours [87].

\section{Synergistic effects of ceragenins with other antibiotics}

Association of ceragenins with the outer membranes of Gramnegative bacteria increases the permeability of the barrier provided by this membrane, [33,34] and this allows improved access of antimicrobials to cytoplasmic targets. In a study designed to assess in vitro synergistic effects of ceragenins, combinations of CSA-13 with colistin, tobramycin, and ciprofloxacin were studied against $P$. aeruginosa strains isolated from cystic fibrosis patients [60]. CSA-13colistin combinations proved the most synergystic (54\% of tested strains), while CSA-13-tobramycin combinations showed the lowest level of synergistic interactions (25\% of tested strains). Bucki et al. [88] demonstrated that a combination of CSA-13 with AMPs, including LL-37, lysozyme, lactoferrin and secretory phospholipase A, enhanced antibacterial activity of CSA-13 against bacteria causing topical infections. This observation is consistent with the hypothesis that endogenous AMPs synergize with administered antimicrobials and antibiotics [89].

\section{Ceragenins in medical devices, coatings, bone fractures and nanoparticles}

Medical devices provide abiotic surfaces on which microorganisms can adhere, form biofilms, and provide a nidus for further infection. For example, biofilms form rapidly on implanted endotracheal tubes, and ventilator-associated pneumoniae is a leading cause of nosocomial infections [90]. Administration of systemic antibiotics does not reduce biofilm burdens and progression to ventilator associated pneumoniae; [91] consequently, there is a need for methods to directly prevent microbial colonization of endotracheal tubes. Endogenous AMPs provide an antimicrobial innate immune function in tissues that controls bacterial growth and protects against biofilm formation [12]. As mimics of endogenous AMPs, ceragenins can provide a comparable, innate immune-like function with the abiotic surfaces found in medical devices.

\section{Incorporation of ceragenins into contact lenses}

Contact lenses, as abiotic surfaces, provide bacteria a scaffold on which biofilm can form, potentially leading to microbial keratitis. AMPs are present in the conjunctival sac, and covalent attachment of AMPs to contact lenses has been shown to inhibit bacterial biofilm formation [92]. However, the costs of AMPs and their susceptibility to proteases complicates their use in contact lenses. Ceragenins offer an attractive alternative, in part due to their antimicrobial activities, relatively low cost and stability; additionally, in the specific context of contact lens manufacture, ceragenins offer these attributes: colorless nature of ceragenins, their solubility in the pre-polymers used to produce lenses, their lack of interference in polymerization processes used in lens formation and the thermal stability of ceragenins, allowing autoclaving of finished products [93,94]. Gu et al. [94] reported that adding an acrylamide group to a ceragenin, giving CSA-120 (Figure 4), allow it to participate in the radical reaction leading to lens formation, thus covalently attaching the ceragenin to the contact lens. With CSA-120 present as $1.25 \%$ of the dry mass of the lens, bacterial biofilm formation was decreased by three logs over 24 hours incubation, when tested in a $10 \%$ nutrient medium. However, this inhibitory effect was not observed in $100 \%$ growth medium, likely because bacteria and bacterial detritus covered the permanently bound ceragenin.

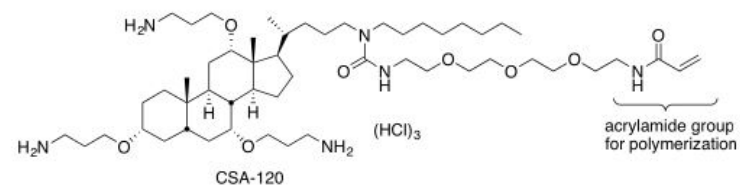

Figure 4: Structure of ceragenin CSA-120, containing an acrylamide group for polymerization.

To circumvent this problem, unbound ceragenin was added to lenses during their formation. A series of ceragenins, with varied lipid character, were added to lenses, and their duration of activity in 
protecting lenses from bacterial colonization were determined. From the series tested, CSA-138 proved to provide the longest lasting protection: with the ceragenin comprising $1 \%$ of the total weight of the lens, bacterial colonization was prevented for up to 30 days with $S$. aureus and for up to 15 days with P. aeruginosa (Figure 5).
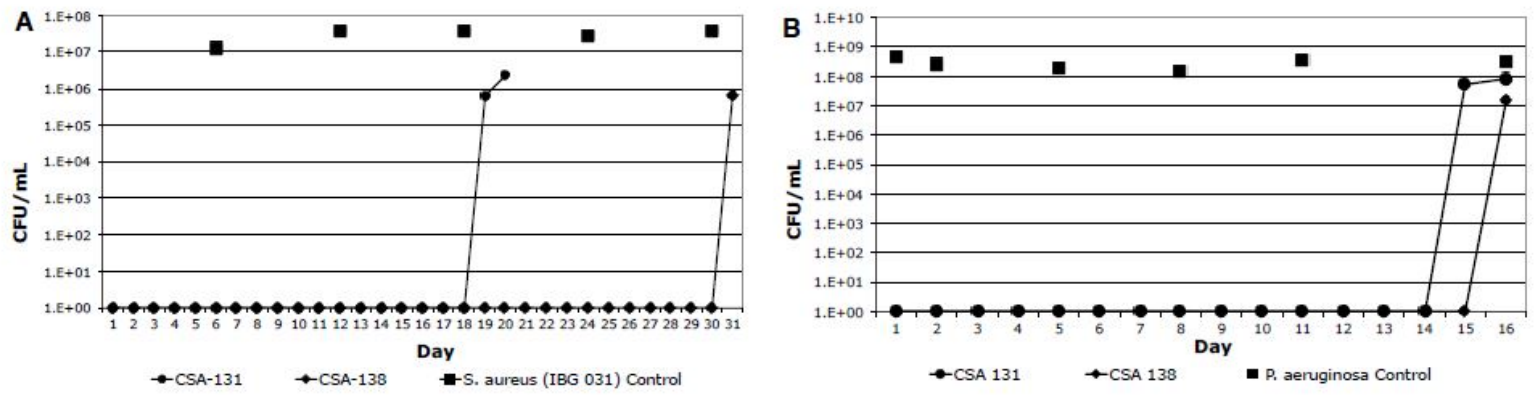

Figure 5: Bacterial populations in nutrient media (10\% TSB in PBS) after initial inoculation with bacteria ( $10^{6}$ CFU) and incubation for 24 hours. Controls were performed with lenses formed without added ceragenin. Lenses contained $1 \%$ of the indicated ceragenin, relative to the dry weight of the lens. After each 24 hours incubation, lenses were placed in fresh media and re-inoculated. A: $S$. aureus (IBG 031); B: $P$. aeruginosa (ATCC 27853).

\section{Medical device coatings containing ceragenins}

Implant-related biofilm infections take a toll on thousands of patients each year [95]. To address this issue, active-release antimicrobial coatings have been designed in which an antimicrobial agent is placed in a coating on an implanted device. The antimicrobial agent is released into the surrounding tissues and fluids with the expectation that it will prevent biofilm growth on the implanted device and also inhibit infection in the surrounding tissue. This approach has been met by limited success [96-98].

Active-release coatings containing ceragenins are attractive because of the bactericidal properties of ceragenins, their activity against established biofilms, their stability in the presence of proteases and other enzymes, and the ease by which they can be manipulated $[4,20,83]$. Williams et al. [99] characterized physical and chemical properties of a coating containing CSA-13 as a novel active release agent in a medical grade polymer coating on fracture fixation plates. Studies of polymerization of the silicone coating demonstrated that incorporation of CSA-13 $(18 \% \mathrm{w} / \mathrm{w})$ did not impact the physical properties of the coating. Even distribution of CSA-13 throughout the coating was observed using SEM.

As a critical aspect of the coating, CSA-13 particles located in the pores of the polymer were released over a span of 30 days in aqueous solution. Determination of thermal stability of the coating indicated that coated materials retain their stability at elevated temperatures, suggesting that the CSA-13-silicone combination was well-suited option for coating implantable devices. To evaluate these coatings in vivo, [22] biofilms of methicillin-resistant $S$. aureus (MRSA) were grown on a polymer mesh to populations of over $10^{9} \mathrm{CFU} / \mathrm{cm}^{2}$. This mesh was implanted against the tibia of sheep and immediately on top of the mesh was placed a fracture fixation plate coated with CSA-13silicone. All control animals developed infection, while those with CSA-13-coated plates were fully protected from infection during a 12week study.

Histology of surrounding tissue showed that the ceragenin was well tolerated, with no evidence of cytotoxicity or interference with wound healing. It was also noted that there was evidence of an increase in bone healing in the presence of the ceragenin. The ability of this coating to prevent infection from infections of medical devices by planktonic bacteria was evaluated in vitro and in vivo by Sinclair et al. $[27,29]$. The coating was applied to porous titanium (Ti) plug implants infected with $5 \times 10^{8} \mathrm{CFU}$ of MRSA [27].

While control mice had to be euthanized shortly after the start of the study due to effects of infection, mice with implants with the polymer coating were protected from infection throughout the 12week study. Notably, release of CSA-13 from the coating did not damage skeletal attachment sites to the porous coated Ti plug implant compared to the control group without CSA-13 coating. Taken together, these in vivo studies show that ceragenins provide an effective innate immune-like function to implanted devices, which are able to eradicate bacteria in both planktonic and biofilm form.

\section{Ceragenins in bone fractures}

Among the "secondary" activities of AMPs is observation that AMPs may influence bone healing [100]. Bone morphogenetic protein-2 (BMP-2) is used clinically to accelerate bone regrowth, [93] and Schindeler et al. [24] investigated whether ceragenins would impact bone regrowth alone and in combination with BMP-2. A series of ceragenins were tested for their impacts on bone regrowth, and they found that CSA-90 displayed the most potent activity. In a rat femurbased model of bone regrowth, with and without infection, they observed that CSA-90 potentiated the activity of BMP-2 and prevented infection from an inoculum of $S$. aureus. In contrast, untreated mice showed declining health and were all euthanized per protocol within two weeks after fracture. Open fractures are frequently complicated by infection, most commonly by pathogens that dwell on the skin such as $S$. aureus, and the ability of CSA-90 to accelerate bone regrowth while preventing infection demonstrates the primary antimicrobial effects of ceragenins as well as the "secondary" activities seen with AMPs.

\section{Ceragenins on nanoparticles}

Metal-based nanoparticles provide a platform from which ceragenins can be presented in a pre-aggregated form. Furthermore, 
the distribution of magnetic nanoparticles in tissues can be controlled and silver nanoparticles display inherent antibacterial activities. Two methods have been used to attach ceragenins to nanoparticles. The first is to use a ceragenin, CSA-124, appended with a thiol group (Figure 6); the thiol coordinates with thiophilic metals, such as silver, generating a monolayer on the surface of the nanoparticles [101,102].

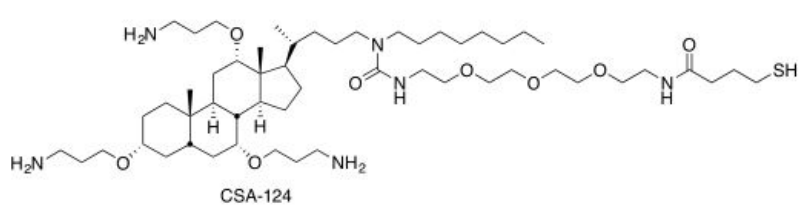

Figure 6: Structure of the thiol-containing ceragenin, CSA-124, for attachment to thiophilic nanoparticles.

The second involves generation of an aldehyde-containing surface on nanoparticles. The amines in ceragenins reversibly form Schiff bases (imines), which allow the nanoparticles to aggregate ceragenins [103]. Hayes et al. [101] prepared silver nanoparticles coated with CSA-124 and found that they were five times more bactericidal than silver alone, with MICs against $S$. aureus and $E$. coli of ca. 12 and 24 ppm respectively. Bucki et al. [103] showed that ceragenin-coated, magnetic nanoparticles retained potent bactericidal activity. In addition, sequestering ceragenins on nanoparticles enhanced biocompatibility. Even without direct conjugation, ceragenins display synergistic antibacterial activity with magnetic nanoparticles [104].

\section{Use of ceragenins in imaging infections}

The primary targets of AMPs and ceragenins are bacterial membranes, and the affinity of these antimicrobials for bacteria has led to efforts to use them for imagining bacterial infections [105]. Diagnostic antimicrobial nanoparticles consisting of CSA-124 bound on a silver shell with a maghemite core were successfully synthesized and introduced as a novel multifunctional theranostic conjugate by Hayes et al. $[88,101]$. Confocal imaging showed that the nanoparticles displayed higher selectivity for $S$. aureus than $E$. coli. In vitro MRI studies demonstrated that nanoparticles were able to adhere to $S$. aureus, indicating the possible application of nanoparticles as diagnostic contrast agents in imaging of deep tissue infections. Roohi et al. [106] investigated technetium (99mTc)-labeling of CSA-13 and abilities of the complex to image infection in mice. The multiple amine groups in CSA-13 allowed stable coordination to the metal ion. Mice were prepared with a $S$. aureus infection in the thigh muscle, and the CSA-13-99mTc complex was administered. Imaging (gamma) showed that the complex accumulated at the infected site and in the kidneys. Zahoor et al. [107] prepared a ceragenin with a separate binding site for technetium; they proposed that affinity for bacterial membranes might increase with the amine groups on the ceragenin free to form ionic interactions. To date, this modified ceragenin has been complexed with technetium and shown to associate with $S$. aureus.

\section{Conclusions}

The roles that AMPs play in maintaining health in higher organisms are multifaceted and include antimicrobial activities against a broad spectrum of pathogens, abilities to sequester endotoxins, and wound healing properties. By mimicking the morphology of AMPs, ceragenins display the same combination of activities and properties. Many of these have been demonstrated through in vitro studies by multiple research groups, and results from a smaller number of in vivo studies have been reported. As the impacts of ceragenins are better understood, their full potential and their limitations in clinical applications will become more apparent. As amphiphilic compounds, concerns about the hemolytic and general cytotoxic properties of ceragenins arise, and these concerns are common to AMPs [108]. For potential systemic applications of ceragenins, hemolytic activity may present an initial concern, and while hemolytic activity with CSA-13 has been observed, it comes at a concentration 10 times higher than bactericidal concentrations [47]. Another study conducted by Garcia et al. [109] showed that CSA-13 at concentration of $10 \mathrm{mg} / \mathrm{ml}$ exhibited less than $10 \%$ hemolysis on human red blood cells and total permeabilization of the cells occurred only at a concentration of 50 $\mathrm{mg} / \mathrm{ml}$.

The amphiphilic nature of ceragenins allows them to associate well with micelles, and Nagant et al. [78] and Leszczynska et al. [88] studied the effects of pluronic F-127 on the cytotoxicity of ceragenins. They found that micelles derived from pluronic F-127 decreased cytotoxicity toward eukaryotic cells and possibly improved antimicrobial activities. Alone CSA-13 toxicity towards human keratinocytes was not significantly different than that of LL-37, and CSA-13 caused no toxicity to HaCat cells at bactericidal concentrations [55]. Bal et al. [110] administered CSA-13 intraperitoneally to mice at varied concentrations and compared the LD50 to efficacious doses of CSA-13. Their conclusion was that "the cytotoxicity of ceragenin CSA-13 is not considerable." Bucki et al. [30] used a fluorophore-labeled form of CSA-13, injected intraperitoneally, in a model of $P$. aeruginosa infection. No adverse events were observed, while bacterial counts were decreased dramatically. Similarly, studies involving medical devices [26,94] and bone regrowth [28] demonstrated no toxicity or local cytotoxicity, suggesting that in these venues ceragenins are well tolerated. Considering potential applications of ceragenins, it is likely that they will find use in localized fashion (e.g., topical treatment for infection) and in specific tissues. AMPs are found in the skin, airways, gastrointestinal tract and reproductive tracts, and ceragenins are well suited for use in these venues. Results with bone regrowth and bonerelated medical devices demonstrate the effectiveness of ceragenins in these localized applications. Further studies are underway to evaluate the potential of harnessing the antimicrobial, anti-inflammatory and wound-healing properties of ceragenins in vivo. Nature has provided a family of compounds, AMPs, that play a central role in innate immunity, while maintaining antimicrobial activity over eons. Mimicry of the morphology of AMPs provides ceragenins with antimicrobial activities as well as "secondary" activities. And there are many potential uses of ceragenins, some of which have been studied in detail and others that are just beginning to be explored.

\section{References}

1. Lau JSY, Kiss C, Roberts E, Horne K, Korman TM, et al. (2017) Surveillance of life-long antibiotics: A review of antibiotic prescribing practices in an Australian Healthcare Network. Ann Clin Microbiol Antimicrob 16: 3.

2. Totsika M (2017) Disarming pathogens: Benefits and challenges of antimicrobials that target bacterial virulence instead of growth and viability. Future Sci 9: 267-269.

3. Ferro G, Guarino F, Cicatelli A, Rizzo L (2017) $\beta$-lactams resistance gene quantification in an antibiotic resistant Escherichia coli water suspension 
treated by advanced oxidation with $\mathrm{UV} / \mathrm{H}_{2} \mathrm{O}_{2}$. J Hazard Mater 323 426-433.

4. Surel U, Niemirowicz K, Marzec M, Savage PB, Bucki R (2014) Ceragenins-A new weapon to fight multidrug resistant bacterial infections. Studia Medyczne 30: 207-213.

5. Mylonakis E, Podsiadlowski L, Muhammed M, Vilcinskas A (2016) Diversity, evolution and medical applications of insect antimicrobial peptides. Phil Trans R Soc B 371: 20150290.

6. Peters BM, Shirtliff ME, Jabra-Rizk MA (2010) Antimicrobial peptides: Primeval molecules or future drugs? PLoS Pathog 6: e1001067.

7. Rodríguez-Hernández MJ, Saugar J, Docobo-Pérez F, de la Torre BG Pachón-Ibáñez ME, et al. (2006) Studies on the antimicrobial activity of cecropin A-melittin hybrid peptides in colistin-resistant clinical isolates of Acinetobacter baumannii. J Antimicrob Chemother 58: 95-100.

8. Ouhara K, Komatsuzawa H, Yamada S (2005) Susceptibilities of periodontopathogenic and cariogenic bacteria to antibacterial peptides, $\beta$-defensins and LL37, produced by human epithelial cells. J Antimicrob Chemother 55: 888-896.

9. Niemirowicz K, Prokop I, Wilczewska AZ, Wnorowska U, Piktel E, et al. (2015) Magnetic nanoparticles enhance the anticancer activity of cathelicidin LL-37 peptide against colon cancer cells. Int J Nanomedicine 10: 3843 .

10. Jenssen H, Hamill P, Hancock REW (2006) Peptide Antimicrobial Agents. Clin Microbiol Rev 19: 491-511.

11. Mahlapuu M, Håkansson J, Ringstad L, Björn C (2016) Antimicrobial Peptides: An emerging category of therapeutic agents. Front Cell Infect Microbiol 6: 194.

12. Park SC, Park Y, Hahm KS (2011) The role of antimicrobial peptides in preventing multidrug-resistant bacterial infections and biofilm formation. Int J Mol Sci 12: 5971-5992.

13. Savage PB (2002) Design, synthesis and characterization of cationic peptide and steroid antibiotics. European J Org Chem 33: 759-768.

14. Mangoni ML, McDermott AM, Zasloff M (2016) Antimicrobial peptides and wound healing: biological and therapeutic considerations. Exp Dermatol 25: 167-173.

15. Steinstraesser L, Koehler T, Jacobsen F, Daigeler A, Goertz O, et al. (2008) Host defense peptides in wound healing. Mol Med 14: 528.

16. Sun Y, Shang D (2015) Inhibitory effects of antimicrobial peptides on lipopolysaccharide-induced inflammation. Mediators Inflamm 2015: 1-8.

17. Li C, Peters AS, Meredith EL, Allman GW, Savage PB (1998) Design and synthesis of potent sensitizers of Gram-negative bacteria based on a cholic acid scaffolding. J Am Chem Soc 120: 2961-2962.

18. Savage PB, Li C, Taotafa U, Ding B, Guan Q (2002) Antibacterial properties of cationic steroid antibiotics. FEMS Microbiol Lett 217: 1-7.

19. Kichler A, Leborgne C, Savage PB, Danos O (2005) Cationic steroid antibiotics demonstrate DNA delivery properties. J Control Release 107: 174-182.

20. Giuliani A, Rinaldi AC (2011) Beyond natural antimicrobial peptides: Multimeric peptides and other peptidomimetic approaches. Cell Mol Life Sci 68: 2255-2266.

21. Chin JN, Jones RN, Sader HS, Savage PB, Rybak MJ (2008) Potential synergy activity of the novel ceragenin, CSA-13, against clinical isolates of Pseudomonas aeruginosa, including multidrug-resistant P. aeruginosa. J Antimicrob Chemother 61: 365-370.

22. Hashemi MM, Rovig J, Weber S, Hilton B, Forouzan MM, et al. (2017) Susceptibility of colistin-resistant, Gram-negative bacteria to antimicrobial peptides and ceragenins. Antimicrob Agents Chemother (in press).

23. Hashemi MM, Savage PB, Hilton B, Weber S (2016) In vitro activity of ceragenins against colistin-resistant clinical isolates of Klebsiella pneumoniae. Global Medical Microbiology Summit \& Expo, San Francisco, California, USA.

24. Durnaś B, Wnorowska U, Pogoda K, Deptuła P, Wątek M, et al. (2016) Candidacidal activity of selected ceragenins and human cathelicidin
LL-37 in experimental settings mimicking infection sites. PloS One 11: e0157242.

25. Pollard JE, Snarr J, Chaudhary V, Jennings JD, Shaw H, et al. (2012) In vitro evaluation of the potential for resistance development to ceragenin CSA-13. J Antimicrob Chemother 67: 2665-2672.

26. Williams DL, Haymond BS, Beck JP, Savage PB, Chaudhary V, et al. (2012) In vivo efficacy of a silicone-cationic steroid antimicrobial coating to prevent implant-related infection. Biomaterials 33: 8641-8656.

27. Sinclair KD, Pham TX, Williams DL, Farnsworth RW, Loc-Carrillo CM, et al. (2013) Model development for determining the efficacy of a combination coating for the prevention of perioperative device related infections: A pilot study. J Biomed Mater Res B Appl Biomater 101: 1143-1153.

28. Schindeler A, Yu NY, Cheng TL, Sullivan K, Mikulec K, et al. (2015) Local delivery of the cationic steroid antibiotic CSA-90 enables osseous union in a rat open fracture model of Staphylococcus aureus infection. J Bone Joint Surg Am 97: 302-309.

29. Sinclair KD, Pham TX, Farnsworth RW, Williams DL, Loc-Carrillo C, et al. (2012) Development of a broad spectrum polymer- released antimicrobial coating for the prevention of resistant strain bacterial infections. J Biomed Mater Res A 100: 2732-2738.

30. Bucki R, Niemirowicz K, Wnorowska U, Byfield FJ, Piktel E, et al. (2015) Bactericidal activity of ceragenin CSA-13 in cell culture and in an animal model of peritoneal infection. Antimicrob Agents Chemother 59: 6274-6282.

31. Olekson M, You T, Savage PB (2017) Ceragenin peptide-mimics inhibit biofilms and affect mammalian cell viability and migration in vitro. FEBS Open Bio 2017 (In Press).

32. Ding B, Yin N, Liu Y, Cardenas-Garcia J, Evanson R, et al. (2004) Origins of cell selectivity of cationic steroid antibiotics. J Am Chem Soc 126: $13642-13648$.

33. Lai XZ, Feng Y, Pollard J, Chin JN, Rybak MJ, et al. (2008) Ceragenins: Cholic acid-based mimics of antimicrobial peptides. Acc Chem Res 41: 1233-1240.

34. Epand RF, Pollard JE, Wright JO, Savage PB, Epand RM, et al. (2010) Depolarization, bacterial membrane composition, and the antimicrobial action of ceragenins. Antimicrob Agents Chemother 54: 3708-3713.

35. Matsuzaki K, Sugishita K, Harada M, Fujii N, Miyajima K (1997) Interactions of an antimicrobial peptide, magainin 2, with outer and inner membranes of Gram-negative bacteria. Biochim Biophys Acta 1327: 119-130.

36. Flannagan RS, Heit B, Heinrichs DE (2015) Antimicrobial mechanisms of macrophages and the immune evasion strategies of Staphylococcus aureus. Pathogens 4: 826-68.

37. Khandelia H, Ipsen JH, Mouritsen OG (2008) The impact of peptides on lipid membranes. Biochim Biophys Acta 1778: 1528-1536.

38. Matamouros S, Miller SI (2015) S. Typhimurium strategies to resist killing by cationic antimicrobial peptides. Biochim Biophys Acta 1848: 3021-3025.

39. Wimley WC (2010) Describing the mechanism of antimicrobial peptide action with the interfacial activity model. ACS Chem Biol 5: 905.

40. Oren Z, Lerman JC, Gudmundsson GH, Agerberth B, Shai Y (1999) Structure and organization of the human antimicrobial peptide LL-37 in phospholipid membranes: relevance to the molecular basis for its noncell-selective activity. Biochem J 341: 501.

41. Kuroda K, Fukuda T, Okumura K, Yoneyama H, Isogai H, et al. (2013) Ceragenin CSA-13 induces cell cycle arrest and antiproliferative effects in wild-type and p53 null mutant HCT116 colon cancer cells. Anticancer Drugs 24: 826-834.

42. Chileveru HR, Lim SA, Chairatana P, Wommack AJ, Chiang IL, et al. (2015) Visualizing attack of escherichia coli by the antimicrobial peptide human defensin 5. Biochemistry 54: 1767-1777.

43. Meincken M, Holroyd DL, Rautenbach M (2005) Atomic force microscopy study of the effect of antimicrobial peptides on the cell 
envelope of Escherichia coli. Antimicrob Agents Chemother 49: 4085-4092.

44. Choi H, Rangarajan N, Weisshaar JC (2016) Lights, camera, action! Antimicrobial peptide mechanisms imaged in space and time. Trends Microbiol 24: 111-122.

45. Ding B, Guan Q, Walsh JP, Boswell JS, Winter TW, et al. (2002) Correlation of the Antibacterial Activities of Cationic Peptide Antibiotics and Cationic Steroid Antibiotics. J Med Chem 45: 663-669.

46. Bucki R, Georges PC, Espinassous Q, Funaki M, Pastore JJ, et al. (2005) Inactivation of endotoxin by human plasma gelsolin. Biochemistry 44: 9590-9597.

47. Bucki R, Sostarecz AG, Byfield FJ, Savage PB, Janmey PA, et al. (2007) Resistance of the antibacterial agent ceragenin CSA-13 to inactivation by DNA or F-actin and its activity in cystic fibrosis sputum. J Antimicrob Chemother 60: 535-545.

48. Isogai E, Isogai H, Takahashi K, Okumura K, Savage PB (2009) Ceragenin CSA-13 exhibits antimicrobial activity against cariogenic and periodontopathic bacteria. Oral Microbiol Immunol 24: 170-172.

49. Lupetti A, Van Dissel J, Brouwer C, Nibbering PH (2008) Human antimicrobial peptides' antifungal activity against Aspergillus fumigatus. Eur J Clin Microbiol Infect Dis 27: 1125-1129.

50. Howell MD, Jones JF, Kisich KO, Streib JE, Gallo RL, et al. (2004) Selective killing of vaccinia virus by LL-37: Implications for eczema vaccinatum. J Immunol 172: 1763-1767.

51. Howell MD, Streib JE, Kim BE, Lesley LJ, Dunlap AP, et al. (2009) Ceragenins: A class of antiviral compounds to treat orthopox infections. J Invest Dermatol 129: 2668-2675.

52. Sevgi M, Toklu A, Vecchio D, Hamblin MR (2013) Topical antimicrobials for burn infections-an update. Recent Pat Antiinfect Drug Discov 8: 161-197.

53. Schmidt EJ, Boswell JS, Walsh JP, Schellenberg MM, Winter TW, et al. (2001) Activities of cholic acid-derived antimicrobial agents against multidrug-resistant bacteria. J Antimicrob Chemother 47: 671-674.

54. Epand RF, Savage PB, Epand RM (2007) Bacterial lipid composition and the antimicrobial efficacy of cationic steroid compounds (Ceragenins). Biochim Biophys Acta 1768: 2500-2509.

55. Leszczyńska K, Namiot D, Byfield FJ, Cruz K, Zendzian-Piotrowska M, et al. (2013) Antibacterial activity of the human host defence peptide LL-37 and selected synthetic cationic lipids against bacteria associated with oral and upper respiratory tract infections. J Antimicrob Chemother 68: 610-618.

56. Bucki R, Namiot DB, Namiot Z, Savage PB, Janmey PA, et al. (2008) Salivary mucins inhibit antibacterial activity of the cathelicidin-derived LL-37 peptide but not the cationic steroid CSA-13. J Antimicrob Chemother 62: 329-335.

57. Delcour AH (2009) Outer membrane permeability and antibiotic resistance. Biochim Biophys Acta, Proteins Proteomics 1794: 808-816.

58. Savage PB (2001) Multidrug-resistant bacteria: Overcoming antibiotic permeability barriers of gram-negative bacteria. Ann Med 33: 167-171.

59. Wnorowska U, Niemirowicz K, Myint M, Diamond SL, Wróblewska M, et al. (2015) Bactericidal activities of cathelicidin LL-37 and select cationic lipids against the hypervirulent pseudomonas aeruginosa strain LESB58. Antimicrob Agents Chemother 59: 3808-3815.

60. Bozkurt-Guzel C, Savage PB, Gerceker AA (2012) In vitro activities of the novel ceragenin CSA-13, alone or in combination with colistin, tobramycin, and ciprofloxacin, against Pseudomonas aeruginosa strains isolated from cystic fibrosis patients. Chemotherapy 57: 505-510.

61. Bozkurt-Guzel C, Savage PB, Akcali A, Ozbek-Celik B (2014) Potential synergy activity of the novel ceragenin, CSA-13, against carbapenemresistant Acinetobacter baumannii strains isolated from bacteremia patients. BioMed Res Int 2014: 1-5.

62. Lim LM, Ly N, Anderson D, Yang JC, Macander L, et al. (2010) Resurgence of colistin: A review of resistance, toxicity, pharmacodynamics, and dosing. Pharmacotherapy 30: 1279-1291.
63. Zhou YF, Tao MT, Feng Y, Yang RS, Liao XP, et al. (2017) Increased activity of colistin in combination with amikacin against Escherichia coli co-producing NDM-5 and MCR-1. J Antimicrob Chemother.

64. Vila-Farres X, Callarisa AE, Gu X, Savage PB, Giralt E, et al. (2015) CSA-131, a ceragenin active against colistin-resistant Acinetobacter baumannii and Pseudomonas aeruginosa clinical isolates. Int J Antimicrob Agents 46: 568-571.

65. Bauer B, Meyer TF (2011) The human gastric pathogen Helicobacter pylori and its association with gastric cancer and ulcer disease. Ulcers.

66. Leszczynska K, Namiot A, Fein DE, Wen Q, Namiot Z, et al. (2009) Bactericidal activities of the cationic steroid CSA-13 and the cathelicidin peptide LL-37 against Helicobacter pylori in simulated gastric juice. BMC Microbiol 9: 187.

67. Trainor EA, Horton KE, Savage PB, Testerman TL, McGee DJ, et al. (2011) Role of the HEFC efflux pump in Helicobacter pylori cholesteroldependent resistance to ceragenins and bile salts. Infect Immun 79: 88-97.

68. Piktel E, Pogoda K, Roman M, Niemirowicz K, Tokajuk G, et al. (2017) Sporicidal activity of ceragenin CSA-13 against Bacillus subtilis. Sci Rep 7: 44452.

69. Vallabhaneni S, Kallen A, Tsay S, Chow N, Welsh R, et al. (2017) Investigation of the first seven reported cases of Candida auris, a globally emerging invasive, multidrug-resistant fungus-United States, May 2013August 2016. Am J Transplant 17: 296-299.

70. Lockhart SR, Etienne KA, Vallabhaneni S, Farooqi J, Chowdhary A, et al. (2017) Simultaneous emergence of multidrug-resistant candida auris on 3 continents confirmed by whole-genome sequencing and epidemiological analyses. Clin Infect Dis 64: 134-140.

71. Pasquale T, Tomada JR, Ghannoun M, Dipersio J, Bonilla H (2008) Emergence of Candida tropicalis resistant to caspofungin. J Antimicrob Chemother 61: 219.

72. Wong JH, Ng TB, Legowska A, Rolka K, Hui M, et al. (2011) Antifungal action of human cathelicidin fragment (LL13-37) on Candida albicans. Peptides 32: 1996-2002.

73. Donlan RM (2002) Biofilms: Microbial life on surfaces. Emerg Infect Dis 8: 881-890.

74. Dosler S, Karaaslan E, Alev Gerceker A (2016) Antibacterial and antibiofilm activities of melittin and colistin, alone and in combination with antibiotics against Gram-negative bacteria. J Chemother 28: 95-103.

75. Moscoso M, García E, López R (2006) Biofilm formation by Streptococcus pneumoniae: Role of Choline, Extracellular DNA, and Capsular Polysaccharide in Microbial Accretion. J Bacteriol 188: 7785-7795.

76. Dong Y, Chen S, Wang Z, Peng N, Yu J (2013) Synergy of ultrasound microbubbles and vancomycin against Staphylococcus epidermidis biofilm. J Antimicrob Chemother 68: 816-826.

77. Debebe T, Krüger M, Huse K, Kacza J, Mühlberg K, et al. (2016) Ethyl Pyruvate: An anti-microbial agent that selectively targets pathobionts and biofilms. PloS One 11: e0162919.

78. Nagant C, Savage P, Dehaye JP (2012) Effect of pluronic acid F-127 on the toxicity towards eukaryotic cells of CSA-13, a cationic steroid analogue of antimicrobial peptides. J Appl Microbiol 112: 1173-1183.

79. Batoni G, Maisetta G, Lisa Brancatisano F, Esin S, Campa M, et al. (2011) Use of antimicrobial peptides against microbial biofilms: Advantages and limits. Curr Med Chem 18: 256-279.

80. Nagant C, Feng Y, Lucas B, Braeckmans K, Savage P, et al. (2011) Effect of a low concentration of a cationic steroid antibiotic (CSA-13) on the formation of a biofilm by Pseudomonas aeruginosa. J Appl Microbiol 111: 763-772.

81. Nagant C, Tré-Hardy M, El-Ouaaliti M, Savage P, Devleeschouwer M, et al. (2010) Interaction between tobramycin and CSA-13 on clinical isolates of Pseudomonas aeruginosa in a model of young and mature biofilms. Appl Microbiol Biotechnol 88: 251-263.

82. Pollard J, Wright J, Feng Y, Geng D, Genberg C, et al. (2009) Activities of ceragenin CSA-13 against established biofilms in an in vitro model of catheter decolonization. Antiinfect Agents Med Chem 8: 290-294. 
83. Nagant C, Pitts B, Stewart PS, Stewart PS, Feng Y, et al. (2013) Study of the effect of antimicrobial peptide mimic, CSA-13, on an established biofilm formed by Pseudomonas aeruginosa. Microbiologyopen 2: 318-325.

84. Boguniewicz M, Leung DYM (2010) Recent insights into atopic dermatitis and implications for management of infectious complications. J Allergy Clin Immunol Pract 125: 4-13.

85. Lara D, Feng Y, Bader J, Savage PB, Maldonado RA, et al. (2010) Antitrypanosomatid activity of ceragenins. J Parasitol 96: 638-642.

86. Polat ZA, Savage PB, Genberg C (2011) In vitro amoebicidal activity of a ceragenin, cationic steroid antibiotic-13, against Acanthamoeba castellanii and its cytotoxic potential. J Ocul Pharmacol Ther 27: 1-5.

87. Polat ZA, Cetin A, Savage PB (2016) Evaluation of the in vitro activity of ceragenins against Trichomonas vaginalis. Acta Parasitol 61: 376-381.

88. Leszczyńska K, Namiot A, Cruz K, Byfield FJ, Won E, et al. (2011) Potential of ceragenin CSA-13 and its mixture with pluronic F-127 as treatment of topical bacterial infections. J Appl Microbiol 110: 229-238.

89. Singh PK, Tack BF, McCray PB, Welsh MJ (2000) Synergistic and additive killing by antimicrobial factors found in human airway surface liquid. Am J Physiol Lung Cell Mol Physiol 279: 799-805.

90. Fernández-Barat L, Torres A (2016) Biofilms in ventilator-associated pneumoniae. Future Microbiol 11: 1599-1610.

91. Stulik L, Hudcova J, Craven DE, Nagy G (2017) Low efficacy of antibiotics against Staphylococcus aureus airway colonization in ventilated patients. Clin Infect Dis 64: 1081-1088.

92. Szczotka-Flynn LB, Pearlman E, Ghannoum M (2010) Microbial contamination of contact lenses, lens care solutions, and their accessories: a literature review. Eye Contact Lens 36: 116-129.

93. Einhorn TA, Majeska RJ, Mohaideen A, Kagel EM, Bouxsein ML, et al. (2003) A single percutaneous injection of recombinant human bone morphogenetic protein-2 accelerates fracture repair. J Bone Joint Surg Am 85: 1425-1435.

94. Gu X, Jennings JD, Snarr J, Chaudhary V, Pollard JE, et al. (2013) Optimization of ceragenins for prevention of bacterial colonization of hydrogel contact lenses. Invest Ophthalmol Vis Sci 54: 6217-6223.

95. Darouiche RO (2004) Treatment of infections associated with surgical implants. N Engl J Med 350: 1422-1429.

96. Hetrick EM, Schoenfisch MH (2006) Reducing implant-related infections: Active release strategies. Chem Soc Rev 35: 780-789.

97. Zilberman M, Elsner JJ (2008) Antibiotic-eluting medical devices for various applications. J Control Release 130: 202-215.

98. Savage PB, Nielsen J, Lai X-Z, Feng Y, Li Y, et al. (2008) Antibacterial activities of thin films containing ceragenins. ACS Publications 65-78.
99. Williams DL, Sinclair KD, Jeyapalina S, Bloebaum RD (2013) Characterization of a novel active release coating to prevent biofilm implant-related infections. J Biomed Mater Res B Appl Biomater 101: 1078-1089.

100. Scott MG, Davidson DJ, Gold MR, Bowdish D, Hancock RE (2002) The human antimicrobial peptide LL-37 is a multifunctional modulator of innate immune responses. J Immunol 169: 3883-3891.

101. Hoppens MA, Sylvester CB, Qureshi AT, Scherr T, Czapski DR, et al. (2014) Ceragenin Mediated Selectivity of Antimicrobial Silver Nanoparticles. ACS Appl Mater Interfaces 6: 13900-13908.

102. Hoppens MA, Wheeler ZE, Qureshi AT, Hogan K, Wright A, et al. (2014) Maghemite, silver, ceragenin conjugate particles for selective binding and contrast of bacteria. J Colloid Interface Sci 413: 167-174.

103. Niemirowicz K, Surel U, Wilczewska AZ, Mystkowska J, Piktel E, et al. (2015) Bactericidal activity and biocompatibility of ceragenin-coated magnetic nanoparticles. J Nanobiotechnology 13: 1-11.

104. Niemirowicz K, Piktel E, Wilczewska AZ, Durnaś, Wątek M, et al. (2016) Core-shell magnetic nanoparticles display synergistic antibacterial effects against Pseudomonas aeruginosa and Staphylococcus aureus when combined with cathelicidin LL-37 or selected ceragenins. Int J Nanomedicine 11: 5443-5455.

105. Nibbering P, Welling M, Van den Broek P, van Wyngaarden KE, Pauwels EK, et al. (1998) Radiolabelled antimicrobial peptides for imaging of infections: A review. Nucl Med Commun 19: 1117-1122.

106. Roohi S, Amir N, Ahmed M, Savage PB, Salahuddin SM, et al. (2009) Preparation, quality control and biological evaluation of $99 \mathrm{mTc}$-labelled cationic steroid antibiotic (CSA-13). Radiochim Acta 97: 57-62.

107. Zahoor R, Roohi S, Ahmad M, Iqbal Z, Amir N, et al. (2013) Synthesis of 99mTc-cationic steroid antimicrobial-107 and in vitro evaluation. J Radioanal Nucl Chem 295: 841-844.

108. Rinaldi AC, Mangoni ML, Anna R, Luzi C, Barra D, et al. (2002) Temporin L: Antimicrobial, haemolytic and cytotoxic activities, and effects on membrane permeabilization in lipid vesicles. Biochem J 368: 91-100.

109. Moscoso M, Esteban-Torres M, Menéndez M, García E (2014) In vitro bactericidal and bacteriolytic activity of Ceragenin CSA-13 against planktonic cultures and biofilms of Streptococcus pneumoniae and other pathogenic Streptococci. PLoS One 9: e101037.

110. Saha S, Savage P, Bal M (2008) Enhancement of the efficacy of erythromycin in multiple antibiotic-resistant Gram-negative bacterial pathogens. J Appl Microbiol 105: 822-828. 